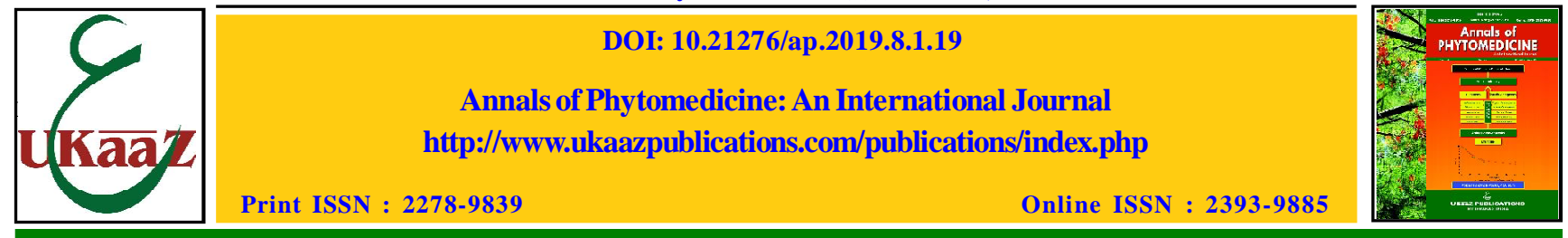

Original article

\title{
Antifungal efficacies of plant extracts against Alternaria solani (Ellis and Martin) Jones and Grout under in vitro condition
}

\author{
B. $\operatorname{Rex}^{\star}$, S. Prabhu* and J. Sandeep Kumar** \\ Department of Plant Pathology, Agricultural College and Research Institute, TNAU, Madurai-625104, Tamil \\ Nadu, India. \\ *Department of Plant Protection, Horticultural College and Research Institute, TNAU, Periyakulam-625604, \\ Tamil Nadu, India. \\ **Department of Agricultural Entomology, Agricultural College and Research Institute, TNAU, Madurai-625104, \\ Tamil Nadu, India.
}

Received April 28, 2019: Revised June 18, 2019: Accepted June 21, 2019: Published online June 30, 2019

\begin{abstract}
The antifungal activity of crude plant extracts of ten plant species, viz., neem (Azadiracta indica), prosopis (Prosopis juliflora), onion (Allium cepa), eucalyptus (Eucalyptus obliqua), pungam (Pongamia pinnata), curry leaf (Murrya koenigii), garlic (Allium sativum), henna (Lawsonia inermis), turmeric (Curcuma longa) and ginger (Zingiber officinale) were evaluated against Alternaria solani (Ellis and Martin) by using poisoned food technique under in vitro conditions. The results showed that turmeric extract recorded minimum radial mycelial growth of $9.50 \mathrm{~mm}$ with maximum per cent inhibition of 89.44 over control. It was followed by garlic observed (12.80 mm, 85.77 per cent) and eucalyptus $(24.27 \mathrm{~mm}, 73.03$ per cent) respectively. Extract of C. longa, A. cepa and E. obliquea reduced conidial germination to $91.11,84.44$ and 80.06 per cent over control, respectively. Thermal stability of extracts were tested against pathogen from preliminary screening; extracts of tested plant species were found to be heat stable and aqueous extracts of $C$. longa showed the highest antifungal activity (10.78 $\mathrm{mm})$, followed by $A$. сера $(13.42 \mathrm{~mm})$. Results of this study indicated that all plant extracts have the antimicrobial activity among all, both extracts of turmeric and garlic were strong inhibitors of this fungus and to levels comparable to standard fungicides.
\end{abstract}

Keywords: Alternaria solani (Ellis and Martin), crude extracts, poisoned food technique, inhibition, antifungal

\section{Introduction}

Tomato (Lycopersicon esculentum Mill) belongs to the Solanaceae family, is one of the most remunerable and widely grown vegetable crop in the world. In world acreage, tomato ranks next to potato among all the vegetables and ranks first among the processing crops. Tomato is grown for its edible fruits, which can be consumed either fresh or in processed form and is a very good source of vitamins, organic acids, essential amino acids and dietary fibres. It occupies number one in their nutrient contribution to human diet. In India, tomato occupies an area of 809 million hectare, with a production of 19696.9 metric tons and productivity of 24.4 metric tons/ha in the year 2016-2017 (Saxena, 2017).

There are many factors infecting tomato, viz., fungi, bacteria, viruses, nematodes and abiotic factors. Among all diseases, early blight disease caused by Alternaria solani (Ellis and Martin) Jones and Grout, is one of the most common and destructive disease of tomato. Early blight disease infecting leaf, stem and fruit are most damaging symptoms and yield losses up to $79 \%$ damage by $A$. solani were reported from India, Canada, USA and Nigeria (Basu,

\footnotetext{
Author for correspondence: Mr. B. Rex

Department of Plant Pathology, Agricultural College and Research Institute, TNAU, Madurai-625104, Tamil Nadu, India.

E-mail: rexpatho@gmail.com

Tel.: +91-9976343940
}

Copyright (c) 2019 Ukaaz Publications. All rights reserved.

Email: ukaaz@yahoo.com; Website: www.ukaazpublications.com
1974; Datar, 1981; Sherf and MacNab, 1986; Mathur and Shekawat, 1986; Gwary and Nahunnaro, 1998).

Chemical fungicides have been used to manage these diseases, but this conduct is associated to negative environmental impacts, potential human exposure to fungicides and residue deposition on the fruits. However, the effectiveness of chemical fungicides has been reduced by development of resistance by the pathogens. Hence, there is a great demand for safer, alternative and effective chemotherapeutic agents (Balakumar et al., 2011; Liu et al., 2013).

Studies have shown that the extracts of medicinal plants have antimicrobial activity against pathogen (Manilal and Idhayadhulla, 2014). The plant extracts of Prosopis juliflora, Carica papaya, Polyalthia longifolia and Ricinus communis are important candidate to develop formulations for the management of A. solani (Kalpashree and Raveesh, 2016). Considering inhibition of mycelial growth and spore germination in vitro and reduction in the development of early blight symptoms in plants in vivo treated with essential oils extracted from E. staigeriana, E. globulus and C. camphora (Tomazoni et al., 2017). In this work, the present investigation was intended to explore in vitro antifungal effect of plant extracts against the pathogenic fungi $A$. solani.

\section{Materials and Methods}

\subsection{Isolation of the fungus Alternaria solani}

The infected leaf was first washed with tap water to remove dust and other contaminants. The periphery of the lesions were cut into 
small bits and surface sterilized with 10 per cent sodium hypochlorite for 5-10 min. In order to remove the residue of the chemical, the tissue bits were washed with three changes of sterile distilled water. The surface sterilized bits were placed on potato dextrose agar (PDA) medium in sterilized petri dishes. These plates were incubated at room temperature $\left(28 \pm 2^{\circ} \mathrm{C}\right)$ for seven days. After incubation, the cultures were purified by hyphal tip method (Dhingra and Sinclair, 1985) and the fungal cultures were maintained separately in agar slants per petri plate. Also, pathogenicity of $A$. solani was proved by Kochs postulates on healthy tomato plants.

\subsection{Collection of plants sample and preparations of plant extracts}

Bioactive natural products were extracted from different plant species with significant antifungal activity, such as neem (Azadiracta indica A. Juss), prosopis (Prosopis juliflora (Sw). Dc), onion (Allium cepa L.), eucalyptus (Eucalyptus obliqua L. Her.), pungam (Pongamia pinnata L.), curry leaf (Murrya koenigii (L.) Sprengel), garlic (Allium sativum L.), henna (Lawsonia inermis L.), turmeric (Curcuma longa L.) and ginger (Zingiber officinale (L.) Roscoe). $100 \mathrm{~g}$ (fresh wt) of mature leaves of above selected plants were homogenized separately in a pre-chilled pestle and mortar using chilled, sterilized distilled water. The extract was filtered through four layers of moistened muslin cloth and the volume was adjusted to $100 \mathrm{ml}$ with distilled water at final. The filtrate was centrifuged at $8000 \mathrm{rpm}, 48^{\circ} \mathrm{C}$ for $15 \mathrm{~min}$. The supernatant thus obtained was designated as concentrated leaf extract (Shekhawat and Prasada, 1971).

\subsection{In vitro effect of plant extracts against pathogen}

The efficacy of plant extracts on the growth of $A$. solan $i$ was studied by poison food technique (Schmitz, 1930). From the standard plant extract $10 \mathrm{ml}$ was added to $90 \mathrm{ml}$ of sterilized and cooled (warm) complete medium and thoroughly mixed by shaking for making 10 per cent concentration. This was plated into sterile petri plates in $20 \mathrm{ml}$ quantities and allowed to solidify. A nine millimetre actively growing culture disc of $A$. solani was aseptically placed onto the medium at the centre of the plate. Three replications were maintained for each treatment. The complete medium without incorporating the plant extract served as control. The plates were incubated at room temperature $\left(28 \pm 2^{\circ} \mathrm{C}\right)$. The diameter of the colony was measured and expressed as per cent growth reduction over control.

$$
\mathrm{PI}=\frac{\mathrm{Dc}-\mathrm{Dt}}{\mathrm{Dc}} \times 100
$$

$$
\begin{aligned}
& \text { Dc }=\text { Average diameter of fungal growth }(\mathrm{cm}) \text { in control } \\
& \text { Dt }=\text { Average diameter of fungal growth }(\mathrm{cm}) \text { in treatment } \\
& \text { PI }=\text { Per cent inhibition }
\end{aligned}
$$

\subsection{Spore germination assay}

About $4.5 \mathrm{ml}$ volume of potato dextrose, broth was pipetted into the test tubes containing $0.5 \mathrm{ml}$ of plant extracts and mixed it thoroughly. At the same time, an aliquot $(100 \mu \mathrm{l})$ of spore suspension (adjusted to $10^{6}$ conidia $\mathrm{ml}^{-1}$ ) was added into each tube. After $24 \mathrm{~h}$ of incubation at $28^{\circ} \mathrm{C}$ on a rotary shaker, a drop of the mixture from each tube was placed in a microscope slide and slides were fixed in lacto-phenol cotton blue and observed spore germination microscopically. The same volume was added in place of plant extracts in the control samples served as a control. A conidium was considered as germinated, if the length of the germ tube was at least half the length of the conidium. The number of germinated conidia was counted out of 100 randomly selected conidia in three replicate slides. Percentage spore germination was calculated according to the following formula:

$$
\text { Spore germination }(\%)=\frac{\text { Germinated spores }}{\text { Total spores }} \times 100
$$

\subsection{Thermal inactivation of plant extracts}

Plant extracts showing potential antifungal activity among the screened plant extracts were further tested for thermal stability. About $1 \mathrm{ml}$ of plant extracts in glass tubes were exposed to $60^{\circ} \mathrm{C}$ in a water bath for $10 \mathrm{~min}$ and cooled to room temperature. Afterwards, the plant extracts were evaluated against $A$. solani by poisoned food technique method.

\subsection{Statistical analysis}

The data were statistically analyzed (Gomez and Gomez, 1984) and the treatment means were compared by Duncan's Multiple Range Test (DMRT). The package used for analysis was IRRI-Stat version 92-a developed by International Rice Research Institute Biometrics Units, Philippines.

\section{Results}

\subsection{Plant extracts against $A$. solani in in vitro}

Of the tested samples obtained from plant species showed antifungal activity against $A$. solani early light disease in tomato plants which shown in Table 1. Among the ten plant extracts, turmeric (Curcuma longa) showed minimal mycelial growth of $9.50 \mathrm{~mm}$ with highest inhibition over control ( 89.44 per cent). This was followed by garlic (A. sativum) and eucalyptus (E. globulus) which observed mycelial growth of 12.80 and $24.27 \mathrm{~mm}$ with inhibition area of 85.77 and 61.60 per cent. Radial mycelial growth and inhibition area over control was observed in ginger (Z. officinale) $(28.35 \mathrm{~mm}$, 68.50 per cent), onion (A. серa) $(34.56 \mathrm{~mm}, 61.60)$, curry leaf (M. koenigii) (46.31 mm, 48.54 per cent), neem (A. indica) $(51.76$ $\mathrm{mm}, 42.48)$ and henna (L. inermis) $(57.18 \mathrm{~mm}, 36.46$ per cent).

Maximum radial mycelial growth and least inhibition was recorded in prosopis ( $P$. juliflora) $(65.57 \mathrm{~mm}, 27.14$ per cent), pungam (O. glabra) (71.18 mm, 20.91 per cent) and the control showed full growth of $A$. solani without any inhibition area (Table 1) (Figure 1)

\subsection{Conidial germination assay}

The plant extract from C. longa, A. sativum and E. globulus showed potent antifungal activity in reducing the spore germination to 91.11 , 84.44 and 80.06 per cent with spore germination of 8.16, 14.28 and 18.36 per cent, respectively. Extract from Z. officinale, A. cepa, $M$. koenigii and $A$. indica showed reduction in condial germination to $75.55,66.67,57.78$ and 48.89 per cent with conidia germination percentage of $22.45,30.61,38.77$ and 46.93 . Lowest conidal germination was observed in L. inermis, $P$. juloflora and P. glabra 
showed 55.10, 63.26 and 75.51 per cent conidial germination with reduction in 39.97, 31.12 and 17.77 per cent over control (Table 2.) (Figure 2).

\subsection{Thermal stability of aqueous extracts on A. solani}

Aqueous extracts of C. longa, A. sativum, E. globulus, Z. officinale, A. cepa, $M$. koenigii and $A$. indica that showed high activity against
A. solani in the preliminary screening were further tested for their thermal stability and for the potency of their aqueous extracts. The results showed that there was no significant difference $(p>0.05)$ between heated $\left(\right.$ at $\left.60^{\circ} \mathrm{C}\right)$ and unheated plant extracts in their efficacy against $A$. solani (Table 3 ). It indicates that the hot water treatment (HWT) temperature range had no effect on the antimicrobial activity of the plant extracts.

Table 1: Antimicrobial effect of different plant extracts on growth of A. solani

\begin{tabular}{|c|l|l|c|c|c|}
\hline S.No. & Botanical name & $\begin{array}{l}\text { Common } \\
\text { name }\end{array}$ & $\begin{array}{c}\text { Parts } \\
\text { used }\end{array}$ & $\begin{array}{c}\text { Mycelial } \\
\text { growth }(\mathbf{m m}) *\end{array}$ & $\begin{array}{c}\text { Per cent inhibition } \\
\text { over control }(\boldsymbol{\%})\end{array}$ \\
\hline 1. & Azadirachta indica A. Juss. & Neem & Leaf & $51.76 \pm 0.33^{\mathrm{g}}$ & 42.48 \\
2. & Prosopis juliflora (Sw.) DC & Prosopis & Leaf & $65.57 \pm 0.24^{\mathrm{i}}$ & 27.14 \\
3. & Allium cepa L. & Onion & Bulb & $34.56 \pm 0.16^{\mathrm{e}}$ & 61.60 \\
4. & Eucalyptus globulus Labill. & Eucalyptus & Leaf & $24.27 \pm 0.34^{\mathrm{c}}$ & 73.03 \\
5. & Pongamia glabra (L.) Pierre & Pungam & Leaf & $71.18 \pm 0.19^{\mathrm{j}}$ & 20.91 \\
6. & Murrya koenigii (L.) Sprengel & Curry leaf & Leaf & $46.31 \pm 0.35^{\mathrm{f}}$ & 48.54 \\
7. & Allium sativum L. & Garlic & Bulb & $12.80 \pm 0.42^{\mathrm{b}}$ & 85.77 \\
8. & Lawsonia inermis L. & Henna & Rhizome & $57.18 \pm 0.24^{\mathrm{h}}$ & 36.46 \\
9. & Curcuma longa L. & Turmeric & Rhizome & $28.35 \pm 0.85^{\mathrm{d}}$ & 89.44 \\
10. & Zingiber officinale (L.) Roscoe & Ginger & & $90.00 \pm 0.14^{\mathrm{k}}$ & 68.50 \\
11. & Control & & $\mathbf{2 . 2 1 5}$ & - \\
\hline
\end{tabular}

* Mean of three replications

\pm represents SE of mean

Means in a column followed by same superscript are not significantly different by Duncan's Multiple Range Test at $p<0.05$.

Table 2: Effect of plant extracts on conidial germination of A. solani

\begin{tabular}{|c|l|c|c|}
\hline S.No. & Botanical name & $\begin{array}{c}\text { Conidial } \\
\text { germination } \\
(\boldsymbol{\%})^{*}\end{array}$ & $\begin{array}{c}\text { Per cent } \\
\text { inhibition } \\
\text { over control }\end{array}$ \\
\hline 1. & Azadirachta indica & $46.93(43.24)^{\mathrm{g}}$ & 48.89 \\
2. & Prosopis juliflora & $63.26(52.69)^{\mathrm{i}}$ & 31.12 \\
3. & Allium cepa & $30.61(33.59)^{\mathrm{e}}$ & 66.67 \\
4. & Eucalyptus globulus & $18.36(25.37)^{\mathrm{c}}$ & 80.06 \\
5. & Pongamia glabra & $75.51(60.37)^{\mathrm{j}}$ & 17.77 \\
6. & Murrya koenigii & $38.77(38.50)^{\mathrm{f}}$ & 57.78 \\
7. & Allium sativum & $14.28(22.20)^{\mathrm{b}}$ & 84.44 \\
8. & Lawsonia inermis & $55.10(47.92)^{\mathrm{h}}$ & 39.97 \\
9. & Curcuma longa & $8.16(16.59)^{\mathrm{a}}$ & 91.11 \\
10. & Zingiber officinale & $22.45(28.28)^{\mathrm{d}}$ & 75.55 \\
11. & Control & $91.83(73.41)^{\mathrm{k}}$ & - \\
\cline { 2 - 4 } & CD $(\boldsymbol{p}=\mathbf{0 . 0 5})$ & $\mathbf{1 . 5 3 2}$ & $\mathbf{2 . 5 6 6}$ \\
\hline
\end{tabular}

*Mean of three replications

*Values in the parenthesis are arcsine transformed

*Means in a column followed by same superscript are not significantly different by Duncan's Multiple Range Test at $p<0.05$.

\section{Discussion}

The investigation of plants containing natural antimicrobial metabolites for plant protection had been identified as a desirable method of disease control (Seema et al., 2011; Dwivedi and Neetu, 2012). Plants were being used against many plant pathogenic fungi. The plant extracts serve as eco-friendly and environment safe biocontrol agents (Swami and Alane, 2013). Efficacy of some plant extracts on seed borne fungi of mungbean seed were reported by Swami and Alane (2013) and found that all the extracts were significantly reduced the fungi at higher concentration.

Table 3: Thermal effect on activity of plant extracts against $A$. solani

\begin{tabular}{|c|l|c|c|}
\hline S.No. & Plant extract & $\begin{array}{c}\text { Thermal } \\
\text { effect }(\mathbf{m m})\end{array}$ & $\begin{array}{c}\text { Without thermal } \\
\text { Effect }(\mathbf{m m})^{*}\end{array}$ \\
\hline 1. & Curcuma longa & $10.78^{\mathrm{a}}$ & $9.96^{\mathrm{a}}$ \\
2. & Allium sativum & $13.42^{\mathrm{b}}$ & $14.12^{\mathrm{b}}$ \\
3. & Eucalyptus globulus & $26.89^{\mathrm{c}}$ & $25.16^{\mathrm{c}}$ \\
4. & Zingiber officinale & $27.32^{\mathrm{d}}$ & $26.10^{\mathrm{d}}$ \\
5. & Allium cepa & $37.46^{\mathrm{e}}$ & $36.71^{\mathrm{e}}$ \\
6. & Control & $89.90^{\mathrm{f}}$ & $90.00^{\mathrm{f}}$ \\
\cline { 2 - 4 } & CD $(\boldsymbol{p = 0 . 0 5 )}$ & $\mathbf{2 . 3 4 0}$ & $\mathbf{1 . 1 1 8}$ \\
\hline
\end{tabular}

* Mean of three replications

* Means in a column followed by same superscript are not significantly different by Duncan's Multiple Range Test at $p<0.05$.

The leaf extract from neem showed high efficacy to inhibit the radial mycelial growth of $A$. solani (43.3 and $26.7 \%$ at $0.1 \%$ and $0.01 \%$, respectively) (Sharma et al., 2007). Various plant products like plant extracts, essential oils, gums, resins, etc., were shown to exert biological activity in vitro and in vivo and were used as biofungicidal compounds (Fawzi et al., 2009; Al-Askar and Rashad, 2010). A. indica, A. cepa and A. sativum showed antifungal property against Alternaria alternata (Lakshman and Ahir, 2011). 


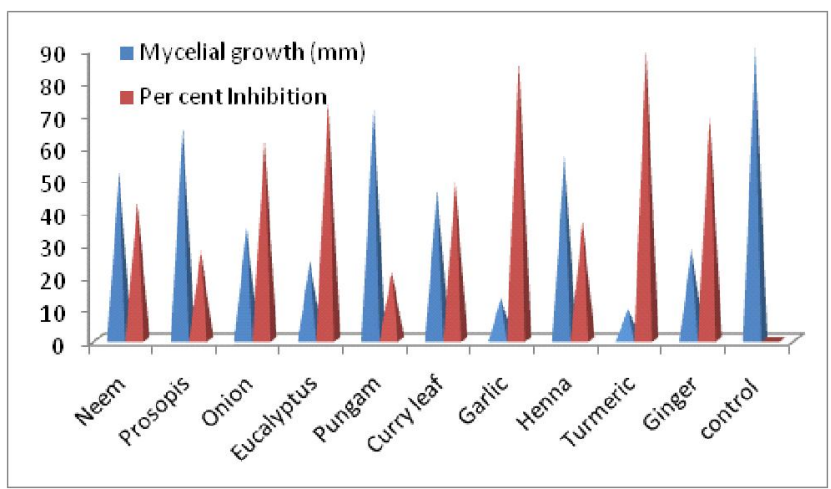

Figure 1: Effect of plant extracts on growth and inhibition of A. solani.

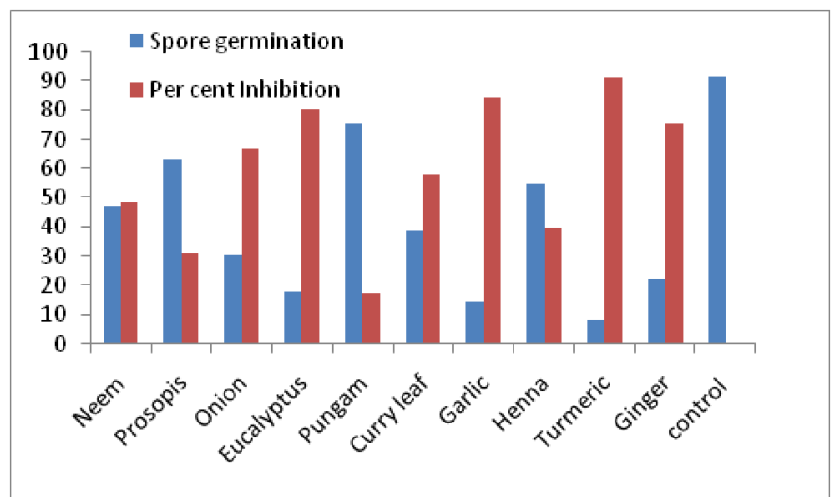

Figure 2: Effect of plant extracts on conidial germination and inhibition of A. solani.

The leaf extract of A. osyrensis showed highest inhibition of $25 \mathrm{~mm}$ against E. coli. The Acronychia pedunculata extracts tested offered maximum RSA (Radical Scavenging Activities) of $65.94 \%$ against E. coli. The antimicrobial activity of $M$. koenigii was estimated by well diffusion method; the maximum antibacterial activity was observed against Pasteurella multocida at $75 \%$ concentration (Mahendra et al., 2016; Gireesha and Raju, 2016; Aslam et al., 2017).

The results showed that the different antimicrobial forms varied in their effectiveness in inhibiting fungi growth. The diversity in the biocomposition of chemical components of plant extracts, i.e., the secondary metabolites of plants, even those obtained from the same species, may result in different responses, especially with regard to the potential for microorganism inhibition (Talibi et al., 2012).

In the preliminary in vitro studies, we observed different crude extracts to completely inhibit the germination of A. solani. Similar potent antagonistic activity of plant extracts has been reported against $A$. solani and several other fungi (Pinto et al., 1998; Kishore et al., 2001). Extract of $P$. juliflora and A. cepa remained highly antifungal even at $1 \%(\mathrm{w} / \mathrm{v})$ concentration. These two plant spp. were well known for their antifungal activity. Extract of $P$. juliflora inhibited the germination of sclerotial Rhizoctonia solani (Ezhilan et al., 1994). The antifungal activity of turmeric extract could be largely due to the presence of alkaloids. Alkaloid fractions of turmeric extract were known for their antifungal activity (Ahmad et al., 1997).
The results are in line with the results of Masih et al. (2015) who observed that the aqueous extracts of $C$. longa showed inhibitory effect on the growth of Aspergillus fumigates, Fusarium solani, Alternaria solani and Helminthosporium spp. Also, the results supported by the findings of Raza et al. (2016) tested five different plant extracts against $A$. solani in vitro and found that all botanical extracts, including $P$. hysterophorus, significantly inhibited mycelial growth of the pathogen. All botanicals have promising antimicrobial activity, among this turmeric extracts showed maximum inhibition of $A$. solani at $10 \%$ concentration after 8 days (Sarfaraz et al., 2018).

The results of thermal inactivation study were supported by previous works (Adegoke et al., 2010) that natural extract components are heat stable under moderate $\left(50-80^{\circ} \mathrm{C}\right)$ heat treatment. In addition, the degree of inhibition of fungal growth was increased from 3.5 to 4 scales in the case of $A$. indica. This is in agreement with the earlier findings (Doughari and Manzara, 2008; El-Mahmood, 2010) that heat treatments increased the activity of plant extracts. This may be due to an increase in the release of active compounds and free radicals (Majumder et al., 1998).

\section{Conclusion}

The antimicrobial activity of the plant extracts against $A$. solani indicates the potential of some plant species as a natural source of fungicidal material. Antifungal activity was confirmed in all the tested plant species, although the results showed that different plant extracts varied in the effectiveness in inhibiting the mycelial growth of A. solani. The results of the present study revealed that extracts from turmeric and garlic have maximum inhibition and minimum conidial germination of $A$. solani. Based on the study, we could conclude that plant extracts serve as a good alternative to chemical fungicides for future eco-friendly antifungal agents, controlling early blight disease of tomato and minimizing risks and hazards for the environment.

\section{Acknowledgments}

This study was supported by Tamil Nadu Agricultural University, Tamil Nadu, India.

\section{Conflict of interest}

The authors declare that no conflict of interest exists in the course of conducting this research. All the authors had final decision regarding the manuscript and the decision to submit the findings for publication.

\section{References}

Adegoke, S.A.; Opata, O.M. and Olajide, J.E. (2010). Antimicrobial activity of the aqueous, methanol and chloroform leaf extracts of Cissus multistriata. Afr. J. Biotechnol., 9:1168-1172.

Ahmad, A.; Ahmad, V.; Khalid, S.M.; Ansari, F.A. and Khan, K.A. (1997). Study on the antifungal efficacy of juliflorine and a benzeneinsoluble alkaloidal fraction of Prosopis juliflora. Phil. J. Sci., 126:175182 .

Al-Askar, A. and Rashad, Y. (2010). Efficacy of some plant extracts against Rhizoctonia solani on pea. J. Plant Prot. Res., 50(3):239-243.

Aslam, I.; Aslam, F.; Qamar, S.; Ishtiaq, S.; Afridi, M.S.K. and Yasmeen, A. (2017). GC-MS analysis and in vitro antibacterial potential of volatile chemical constituents from leaves of Murraya koenigii L. Spreng. Ann. Phytomed., 6(1):143-147. 
Balakumar, S.; Rajan, S.; Thirunalasundari, T. and Jeeva, S. (2011). Antifungal activity of Aegle marmelos (L.) Correa (Rutaceae) leaf extract on dermatophytes. Asian Pacific Trop Biomed., 1(4):309-312.

Basu, P. (1974). Measuring early blight, its progress and influence on fruit losses in nine tomato cultivars. Can. Plant Dis. Surv., 54(2): 45-51.

Datar, V. (1981). Assessment of losses in tomato yields due to early blight. Indian Phytopathol., 34:191-195.

Dhingra, O. D. and Sinclair, J. B. (1985). Plant Path. Meth., CRC Press, Inc.

Doughari, J.H. and Manzara, S. (2008). In vitro antibacterial activity of crude leaf extracts of Mangifera indica Linn. Afr. J. Microbiol. Res., 2:67-72.

Dwivedi, S. and Neetu, N. (2011). Antifungal activity of some plant extracts against guava wilt pathogen. Int. J. Environ. Sci., 3(1):412-420.

El-Mahmood, A.M.; Doughari, J.H. and Kiman, H.S. (2010). In vitro antimicrobial activity of crude leaf and stem bark extracts of Gmelina arborea (Roxb) against some pathogenic species of Enterobacteriaceae Afr. J. Pharm. Pharmacol., 4:355-361.

Ezhilan, J.G.; Chandrasekar, V. and Kurucheve, V. (1994). Effect of six selected plant products and oil cakes on the sclerotial production and germination of Rhizoctonia solani. Indian Phytopathol., 47:183185 .

Fawzi, E.; Khalil, A. and Afifi, A. (2009). Antifungal effect of some plant extracts on Alternaria alternata and Fusarium oxysporum. Afr. J. Biotechnol., 8(11):210-217.

Gireesha, J. and Raju, N.S. (2016). Phytochemical analysis, antibacterial and antioxidant potential of Acronychia pedunculata (L.) Miq. Ann. Phytomed., 5(2):147-151.

Gomez, K. A. and Gomez A.A. (1984). Statistical Procedures for Agricultural Research, John Wiley and Sons.

Gwary, D. and Nahunnaro, H. (1998). Epiphytotics of early blight of tomatoes in Northeastern Nigeria. Crop Prot., 17(8):619-624.

Kalpashree, M.M. and Raveesha, K.A. (2016). Efficacy of aqueous plant extracts against Alternaria solani, the causative agent of early blight of tomato. International J. Herb. Med., 4(6):184-188.

Kishore, G.K.; Pande, S. and Rao, J.N. (2001). Control of late leaf spot of groundnut (Arachis hypogaea) by extracts from non-host plant species. Pl. Pathol. J., 17:264-270.

Lakshman P.B. and Ahir. R.R. (2011). Evaluation of plant extracts and biocontrol agents against leaf spot disease of brinjal. Indian Phytopathol., 64(4):378-380.

Liu, C.; Zhao, C.; Pan, H.H.; Kang, J.; Yu, X.T.; Xie, Z. and Chen, R.T. (2013) Chemical constituents from Inonotus obliquus and their biological activities. J. Natural Prod., 77(1):35-41.

Mahendra, C.; Manasa, G.; Murali, M.; Amruthesh, K.N.; Sudarshana, M.S. and Lingaraju, D.P. (2016). Antibacterial and antioxidant properties of Argyreia osyrensis Roth. Ann. Phytomed., 5(1):110-115.
Majumder, A.M.; Upadhyay, A.S. and Pradhan, A.M. (1998). Effect of Azadirachta indica leaf extract on carbon tetrachloride induced hepatic, damage in albino rats. Ind. J. Pharm. Sci., 60:363-367.

Manilal, A. and Idhayadhulla, A. (2014). Potential in vitro antimicrobial efficacy of Holigarna arnottiana (Hook F). Asian Pacific journal of Tropical Biomedicine, 4(1):25-29.

Masih, H.; Peter J.K. and Taripathi, P. (2015). A comparative evaluation of antifungal activity of medicinal plant extracts and chemical fungicides against four plant pathogens. Int. J. Curr. Microbiol. App. Sci., 3(5):97-109.

Mathur, K. and Shekhawat, K. (1986). Chemical control of early blight in kharif sown tomato. Indian J. Mycol. Pl. Pathol., 16(2):235-236.

Pinto, C.M.F.; Maffia, L.A.; Casali, V.W.D. and Cardoso, A.A. (1998). In vitro effect of plant leaf extracts on mycelial growth and sclerotial germination of Sclerotium cepivorum. J. Phytopathol., 146:421425.

Raza, W.; Ghazanfar, M.U.; Iftikhar, Y.; Ahmed, K.S.; Haider N. and Rasheed, M.H. (2016). Management of early blight of tomato through the use of plant extracts. Int. J. Zool. Stud., 1(5):1-4.

Sarfraz, M.; Khan, S.A.; Moosa, A.; Farzand, A.; Ishaq, U.; Naeem, I. and Khan. W.A. (2018). Promising antifungal potential of selective botanical extracts, fungicides and Trichoderma isolates against Alternaria solani. Cer. Agron. Mold., 1(173):65-74.

Saxena, M. (2017). Indian horticulture database-2017. National Horticulture Borad.

Schmitz, H. (1930). Poisoned food technique. Industrial and Engineering Chemistry-Analytical Edition., 2(4):361-363.

Seema, M.; Sreenivas, S.; Rekha, N. and Devaki, N. (2011). In vitro studies of some plant extracts against Rhizoctonia solani Kuhn infecting FCV tobacco in Karnataka Light Soil, Karnataka, India. J. Agrl. Techn., 7(5):1321-1329.

Sharma, A.; Dass, A. and Paul, M. (2007). Antifungal effect of neem extract on some common phytopathogenic fungi. Advan. Plant Sci., 20(2): 357.

Shekhawat, P.S. and Prasada. R.L. (1971). Antifungal activities of some plant extracts. Inhibition of spore germination. Indian Phytopathol., 24:800-802.

Sherf, A. and MacNab, A. (1986). Vegetable diseases and their control (John Wiley and Sons). New York, United States, pp:728.

Swami, C. and Alane, A. (2013). Efficacy of some botanicals against seedborne fungi of green gram (Phaseolus aureus Roxb.). Biosci. Dis., 4(1): 107-110.

Talibi, I.; Askarne, L.; Boubaker, H.; Boudyach, E.; Msanda, F.; Saadi, B. and Aoumar, A.A. (2012). Antifungal activity of some Moroccan plants against Geotrichum candidum, the causal agent of postharvest citrus sour rot. Crop Prot., 35:41-46.

Tomazoni, E.Z.; Pauletti, G.F.; Ribeiro, R.T.S.; Moura, S. and Schwambach, J. (2017). In vitro and in vivo activity of essential oils extracted from Eucalyptus staigeriana, Eucalyptus globulus and Cinnamomum camphora against Alternaria solani Sorauer causing early blight in tomato. Sci. Hortic., 223:72-77.

Citation: B. Rex, S. Prabhu and J. Sandeep Kumar (2019). Antifungal efficacies of plant extracts against Alternaria solani (Ellis and Martin) jones and grout under in vitro condition. Ann. Phytomed., 8(1):148-152. 